\title{
The Effect of Using Process Approach on Students' Writing of Descriptive Text
}

\author{
Qisthi Amalia ${ }^{1}$, Zaharil Anasy ${ }^{2}$, Ratna Sari Dewi ${ }^{3}$ \\ \{qisthi.amalia15@mhs.uinjkt.ac.id ${ }^{1}$, zaharil.anasy@uinjkt.ac.id ${ }^{2}$, ratna@uinjkt.ac.id ${ }^{3}$ \} \\ ${ }^{1,2,3}$ UIN Syarif Hidayatullah Jakarta, Indonesia
}

\begin{abstract}
The aim of this study was to find the empirical evidence of the effectiveness of Process Approach on students' ability of writing descriptive text at the tenth-grade of SMAN 87 Jakarta. The population of this study was tenth-grade students of SMAN 87 Jakarta. The sample was 60 students chosen through purposive sampling technique and was divided into two classes; experimental class and controlled class. The method used in this study was a quantitative method using quasi-experimental design. Research instruments used in this study was a set of writing tests which was given at the beginning of the study and at the last meeting after the treatments by using Process Approach were applied. The data was analysed by using t-test. The result that was gained from this study had shown the differences of students' scores in writing descriptive text by using Process Approach and without using Process Approach. The presented result of p-value of posttest score was 0.011 with the level of significance $5 \%(0.05)$. In other words, it can be concluded that p-value $(0.011)<\operatorname{sig} \alpha=0.05(5 \%)$. In addition, the effect size result was 0.7. It proves that using Process Approach was effective at a moderate level on students' writing descriptive text at the tenth-grade of SMAN 87 Jakarta in academic year 2018/2019.
\end{abstract}

Keywords: Writing of Descriptive Text, Process Approach

\section{Introduction}

In Industrial Revolution 4.0 (era Revolusi Industri 4.0) literacy culture among students including reading and writing skills are needed to be improved. For instances, with a variety of advanced technology and strong information flow, Indonesian students must be able to improve their writing skills in order adjust themselves to the industrial revolution era by utilizing the advanced technology. Therefore, by having fine writing skill, students can spread positive information and also improve their skills and expand their knowledge through writing [1]

In Indonesia, the government stated that writing skill is must be taught at school and it has been written in the education curriculum. In addition, senior high school students in Indonesia are required to study writing descriptive text. As written in Kompetensi Dasar 3.4 of Curriculum 2013: "Membedakan fungsi sosial, struktur teks, dan unsur kebahasaan beberapa teks deskriptif lisan dan tulis dengan memberi dan meminta informasi terkait tempat wisata dan bangunan bersejarah terkenal, pendek dan sederhana, sesuai dengan konteks penggunaannya." Therefore, writing descriptive text is important and should be taught and mastered both by teachers and students. 
However, learning writing of descriptive text has become more demanding since the new development of English Language Curriculum 2013 has been enacted. There are many components that should be mastered by students in descriptive text such as grammar, spelling, content, conjunction, choice of words, and mechanism of the text in order to produce a unified paragraph [2]. In order to solve the problem in writing descriptive text, the teacher should encourage students' to write creatively and to express their ideas without being afraid of making mistakes.

Nevertheless, there is an approach namely Process Approach which believed could help English teachers enhance their teaching in classroom and also help students to produce better writing. Process Approach is considered as an approach which can be used to enhance the learning process and by using Process Approach, students would learn on how to focus on their process of writing. According to I. S. P. Nation, Process Approach is an approach which considers writing as a process. In order to make a good writing, students should understand of how the writing has produced not only on the writing results' but also on the process of writing [3].

The question that has been formulated in this study is whether there were any significant effects of Process Approach on students' writing ability of descriptive text when it has been implemented in learning.

This paper contains the literature review of writing descriptive text and Process Approach, the methodology, the steps to implementing Process Approach in learning writing, the results and suggestions of the research, and the conclusion of the research.

\section{Literature Review}

Writing descriptive text generally shares some characteristics with the other kinds of writing. It purposes to explain the topic in the text or to tell the reader about something. However, in writing descriptive text, the writer needs to describe the subject of the text in more detail by using vivid nouns and verbs in order to make the readers have better imagination about the subject.

In addition, the writer also needs to check the errors of grammar and spelling in order to produce a good descriptive text [4][5]. In teaching writing descriptive text, teacher can use many approaches, methods, or techniques in order to enhance students' ability.

One of the approaches that has been proved to be useful in learning writing descriptive text is Process Approach.

Process Approach is an approach that focused on the process of the writing. On its implementation, Process Approach focuses on some stages in the writing process namely prewriting phases, drafting, revising and editing or proofreading [6][7].

Several studies that have been conducted by the experts had shown the advantages of Process Approach in learning. Process Approach encouraging students to write creatively in order to make students able to communicate effectively through their ideas of the writing.

Process Approach becomes advantageous because this approach gives an understanding to the students about the process of the writing. Students would be experiencing themselves as the writer who shares their ideas in writing to the reader. Furthermore, Process Approach does not only focus on the product of the writing which can omit the displeasure of traditional product approach. Moreover, by using Process Approach, students can discuss and work in pair and doing brainstorming in order to choose the topic for their writing. For examples, students can discuss with their friends or the teacher about the content of the writing, students also can share their ideas with their peers in a classroom. In addition, peer correction and group evaluation are also encouraged on Process Approach [8].

\section{Methodology}

Quantitative method and quasi-experimental design was used in this research since this research aims to find the empirical evidences of the advantages in using Process Approach on students' writing descriptive text. Quantitative research is a social research that uses empirical methods and empirical statements. Moreover, a quantitative research as a type of research that 
obtained numerical data that would be analysed by using mathematical method, or to be more specific, by using statistics [9]. Meanwhile, a quasi-experimental design uses two classes. The first class would serve as experimental class that will be taught by a treatment and the second class would serve as controlled class that will not be given a treatment [10]. The rationale behind the application of this method is because this research needs to find out whether the independent variable (Process Approach) has a significant effect towards the dependent variable (students' ability in writing descriptive text).

The population of this study was the tenth-grade students of SMAN 87 Jakarta, academic year 2018/2019. It consists of 210 students divided into seven classes. Furthermore, two classes: X IPS 2 and X IPS 3 will serve as samples of the research.

The instrument used in this research is a set of writing tests of descriptive text. The test was divided into pre-test and post-test. The pre-test was given before Process Approach was being implemented on learning and post-test was given after the treatment by using Process Approach was being implemented on experimental class.

Furthermore, the collected data were analysed by using statistical analysis. Then, the data from experimental class and controlled class were being compared. The t-test was used in analysing the data to know the effect of using Process Approach on students' writing ability of descriptive text. Below is the table of the research design:

Table 1. The Research Design

\begin{tabular}{|l|l|l|l|}
\hline $\begin{array}{l}\text { Study } \\
\text { Population }\end{array}$ & $\begin{array}{l}\text { Before/pre- } \\
\text { observation }\end{array}$ & $\begin{array}{l}\text { Technique/ } \\
\text { intervention }\end{array}$ & $\begin{array}{l}\text { After/post } \\
- \\
\text { Observati } \\
\text { on }\end{array}$ \\
\hline $\begin{array}{l}\text { Controlled } \\
\text { Group }\end{array}$ & Pre-test & $\begin{array}{l}\text { No } \\
\text { experiment } \\
\text { al treatment } \\
\text { (lecturing, } \\
\text { group } \\
\text { discussion, } \\
\text { individual } \\
\text { task) }\end{array}$ & Post-test \\
\hline $\begin{array}{l}\text { Experiment } \\
\text { al }\end{array}$ & Pre-test & $\begin{array}{l}\text { Experiment } \\
\text { al treatment } \\
\text { (lecturing, } \\
\text { and using } \\
\text { Process } \\
\text { Approach) }\end{array}$ & Post-test \\
& & & \\
\hline
\end{tabular}

\section{Implementation of Process Approach in Experimental Class}

Four major stages in writing are pre-writing, drafting, revising, and editing. The description of these four major steps would be described as follows:

a. Pre-writing

Pre-writing stage is a first stage in process of writing, this stage helps the writer to develop ideas for the writing when the writer does not have any clues or inspiration in writing. This stage is called pre-writing stage because this stage was done before the writer create a first draft.

b. Drafting

Drafting stage is a stage where the ideas that have been obtained from pre-writing stage are being written down into a first draft. In common, a first draft is also called rough draft; the material inside a first draft is very basic and can be revised on the next writing stage.

c. Revising 
In revising stage, there are many components on writing that should be noticed by the writer such as the content of the writing, the arrangement of ideas, and also sufficient evidences to support the ideas in writing. This stage would take much time and also could be the most difficult part of the writing process.

d. Editing

Editing stage is the last stage of writing process. In editing, the writer is needed to check for errors and eliminate these errors thus the writing can be free of errors [11].

In line with Barbara Fine Clouse, also proposed several procedures in using Process Approach are:

1. Freewriting: students discover ideas for their writing. After that, students would gain information which related to the topic. Then, students can do free writing where students can write as many words as possible related to the topic of their writing.

2. Drafting: students create a first draft based on the topic sentence of the writing. It is also possible to have more than one draft. In drafting stage, grammar, spelling, or punctuation should not be the primary concerns.

3. Revising: students could possibly add, shift, or delete some materials of the writing when working in revising stage by revising it individually or with others.

Moreover, here are some of the revision priority lists in revising stage:

a. Content: students are tend to give more attention to the clarity of the ideas, check the sufficient examples or details of the writing, and not to look at the unnecessary points, examples, or details that are not important or would distract the readers from the main idea.

b. Organization: students can see the clarity of topic or thesis statement, the overall organizational patterns, the punctuation, transition, or connection between each word, and the conclusion of the text.

c. Style: students can delete some words that not working well, checking the meaning of sentence in writing, eliminate unnecessary words, add some new words, and give attention to the length, type, and beginning of the sentences, and also check if there are some sentence that need to be tighten or words with no purpose that need to be deleted.

d. Mechanics: students are needed to check grammar, spelling, and punctuation of their writing.

Editing and Proofreading: After doing some revision for the material, organization, and style, students are asked to pay attention on a few kinds of errors. The main concern in editing is on the mechanism. Furthermore, for the final step of Process Approach, students were to read their final draft that had been recently edited in order to eliminate all the possible errors in the mechanicsm of writing. There are some way to do proofreading such as check for typographical errors, font size, line spacing, margins, and title [12].

Based on the statements of two experts above, Process Approach is commonly consists of four main stages. All of the stages are having same procedures and instructions at each stage although the terms used by the two experts are different.

From statements above, the writer sums up the procedures in using Process Approach are:

1. Students determine the topic of their writing and collect information related to the topic of the writing.

2. Students do free writing where they write down as many words as possible related to the topic of their writing on their paper.

3. Students create a first draft which consists of 150 to 200 words. In addition, grammar, spelling, and punctuation should not be the main focus.

4. Students could possibly add, shift, or delete some materials of the writing. Furthermore, students need to focus on the content, organization, style, and mechanism of the writing.

5. Students read the paper to find a few kinds of errors and make a list or chart of common errors of the writing.

6. Students read their final draft to check spelling, grammar, or typographical errors. 


\section{Method Used in Controlled Class}

The learning method used in controlled class is Scientific Approach consists of several steps that need to be done by students. First, observing stage, in this stage the writer activates students' background of the material that will be learned by showing pictures or video related to the learning material. Second, questioning stage, the writer gives some examples related to the material and gives students chances to ask questions. Third, associating stage, the writer explains things that need to be known by students related to the material and students are asked to discuss with their friends about things related to the learning material. Fourth, experimenting, in this stage students are asked to do an experiment and create their own material based on the information that has been obtained and discussion that has been done. Fifth, communicating, this stage aims to make students active in learning, students are asked to present their own material in front of the class or tell about their creation to their friends.

\section{Population and Sample of the Research}

The population of this study was the tenth-grade students of SMAN 87 Jakarta, academic year 2018/2019. It consists of 210 students divided into seven classes. The writer chose this population because the writer expected the students to have an adequate understanding of writing especially in writing descriptive text.

The writer used purposive sampling in taking sample. Purposive sampling is used in a special situation. This type of sampling is usually used in exploratory research or field research. The judgment of experts is used in selecting cases.

In this research, there will be two classes which are taken as the sample. One class will serve as the experimental class and the other class will serve as the controlled class. Those classes will be chosen based on the information from their English teacher about the average scores of writing of the two classes. The writer will took the sample of the research based on the situation of the class and the information from the English teacher.

Furthermore, two classes: X IPS 2 and X IPS 3 will serve as samples of the research. Based on the interview with the English teacher, the writer knew that X IPS 2 had higher writing scores and X IPS 3 had lower writing scores. Therefore, the writer decided to choose $\mathrm{X}$ IPS 2 as the experimental class to examine the writing ability of students after treated by using Process Approach and, X IPS 3 will serve as the controlled class respectively.

\section{Results and Suggestions}

The result of this quasi-experimental research has indicated that Process Approach was effective on students' ability of writing descriptive text at tenth-grade of SMAN 87 Jakarta in academic year of 2018/2019. Based on the calculation of effect size, it was also confirmed that the effectiveness was at moderate level of significance.

Based on the statistical analysis, the increasing point of experimental class is 6.8 points; from 73.3 to 80.1 . For the control class, the mean score has increasing point of 2.1 points; from 74 to 76.1 . It means that in experimental class, the points was been increased more significantly rather than the controlled class.

Moreover, the independent-sample t-test of data analysis had shown statistically the effectiveness of using Process Approach during the period of treatment. A statistical significance shown by the analysis of post-test data had resulted that p-value or sig (2-tailed) = 0,011 that is lower than sig a $=0.05$. The statistical result indicates that the null hypothesis (Ho) is rejected and the alternative hypothesis (Ha) is accepted. Therefore, it can be concluded that Process Approach has an effect on students' writing ability of descriptive text. In addition, 
the calculation of effect size adapted from Cohens' $d$ also revealed the level of effectiveness on using Process Approach. The result of the effect size is 0.7, which indicates that Process Approach is moderately effective in this research.

Based on the research that has been conducted, the writer concludes that Process Approach gives the effect on students' writing descriptive text. Therefore, there are some suggestions for English teacher, students, and other researchers:

1. For English Teacher

Teacher might apply Process Approach to help students increase their writing achievement. Moreover, teacher should prepare the learning material and strategy and manage time effectively in the classroom when using Process Approach in order to achieve maximum results. In addition, the teacher should make conducive learning situation in the classroom when applying Process Approach as the teaching strategy. Also, the teacher should be able to supervise students' attention, involvement, and engagement in the learning process.

2. For Students

Students should maximize their time on learning and be able to be more active and focus on the learning activities while Process Approach is implemented.

3. For Other Researchers

The result of this study could be the basic references for other researchers who want to conduct a similar research about the effect of using Process Approach in writing of descriptive text.

\section{Figures}

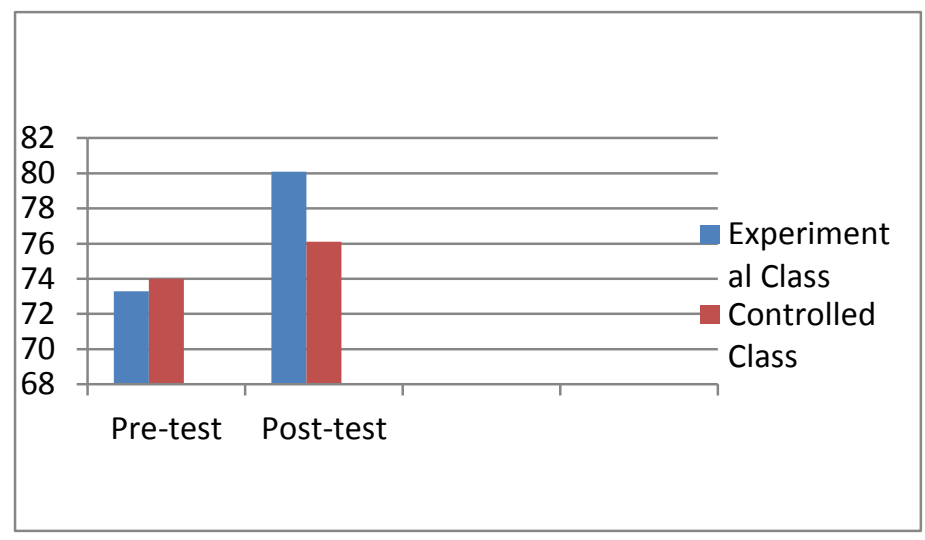

Fig. 8.1. The Difference between Students' Score in Experimental Class and Controlled Class

\section{Conclusion}

Based on the research findings, Process Approach is moderately effective on improving students' writing ability of descriptive text. It is proved by the result of independent-sample ttest which shown p-value (2-tailed) $=0.011$ in post-test scores on experimental class and controlled class. The number of p-value (2-tailed) in this research is less than the referred significance level of sig a $=0.05(5 \%)$.

Furthermore, because of the obtained $\mathrm{p}$-value in this research is lower than the sig a $=0.05$ $(5 \%)$, it can be concluded that there is a statistical significance or effectiveness. In other words, when p-value is lower than the sig a $=0.05(5 \%)$, means that the alternative hypothesis (Ha) is accepted and the null hypothesis (Ho) is rejected. In addition, the result of the effect size calculation adapted from Cohen's $d$ shows a value of 0.7 . It means that the level of significance ranged at the moderate level. 
In conclusion, the alternative hypothesis (Ha) is accepted and the null hypothesis (Ho) is rejected. In other words, it proves that Process Approach was effective on students' writing descriptive text at the tenth-grade of SMAN 87 Jakarta in academic year 2018/2019.

Despite the positive result of statistical data, the statistical calculation is needed to be supported by the interview results from five students in the experimental class that gave their opinion about the strengths and weaknesses on the implementation of Process Approach in the classroom.

From the interviews, most students found that Process Approach was helpful to guide them understanding the process of writing descriptive text. Also, the students thought that using Process Approach made them easier to discover ideas for their writing because there will be a stage called Freewriting in Process Approach.

However, there are few negative responses that arose from the use of Process Approach in the classroom. Some students thought that Process Approach was time-consuming, because there are several stages where students created their own writing. Thus, the teacher needs to allocate a larger time when implementing Process Approach in the classroom.

Acknowledgments. The writer would like to thank the English teachers, all of the school staff and students of SMAN 87 Jakarta, especially the students of X IPS 2 and X IPS 3 who helped the writer in conducting this research.

\section{References}

[1] Bishop, Wendy: On Writing: A Process Reader. New York: McGraw Hill (2004)

[2] Suriyanti, Sufatmi: Exploring Teacher Strategies in Teaching Descriptive Writing in Indonesia. In: Eric Journal. 13 (2). pp.74 (2016)

[3] Nation, I. S. P. (ed.): Teaching ESL/EFL Reading and Writing. New York: Routledge (2009)

[4] Spencer, Lauren: The Library of Writing Skills A Step-by-Step Guide to Descriptive Writing. The Rosen Publishing Group. New York, $1^{\text {st }}$ edition (2005)

[5] Hutchinson, Emily: Desciptive Writing. California: Saddleback Publishing (2005)

[6] Harmer, Jeremy: How to Teach Writing. London: Pearson Education (2004)

[7] Buscemi, Santi V: A Reader for Developing Writers. Boston: McGraw-Hill (2005)

[8] Al-Sawalha, Abdulla Musa: Potential Advantages of Process Writing For Students English Language and Literature at Jerash University in Jordan. In: Arc Journal. 2 (6). pp. 42. (2014)

[9] Suphat, Sukamolson: Fundamentals of quantitative research. In: PASAA Journal. pp. 1-2. (2007)

[10] Wiersma, William and Stephen G Jurs. Research Methods in Education. Boston: Pearson Education (2009)

[11] Barbara, Fine Clouse: 265 Troubleshooting Strategies for Writing Non-fiction. New York: McGraw-Hill. (2005)

[12] Brannan, Bob: A Writer's Workshop: Crafting Paragraphs, Building Essays. New York: McGraw Hill. $2^{\text {nd }}$ edition. (2006) 
